Warszawskie Studia Pastoralne UKSW

Rok XI 2016 Nr 3 (32)

Ks. Ryszard Selejdak

(Kongregacja do Spraw Duchowieństwa-Rzym)

\title{
NIEKTÓRE ASPEKTY PRAWNE DIAKONATU STAŁEGO
}

Some Juridical Aspects of the Permanent Diaconate

\section{Wprowadzenie}

Ojcowie Soboru Watykańskiego II (1962-1965), po upływie niemal tysiąca lat, postanowli, aby w Kościele łacińskim ponownie przywrócić diakonat jako samodzielny i stały stopień hierarchiczny celibatariuszy lub ludzi żyjących w małżeństwie. Należy jednak podkreślić, że intencją Soboru nie było przywrócenie starożytnej formy posługi diakona, ale wyraźna odnowa tej posługi w świetle nowej koncepcji władzy świętej oraz potrzeb duszpasterskich Kościołów partykularnych ${ }^{1}$. Na skutek decyzji Ojców Soborowych, dla diakonatu stałego otwarł się trudny, ale żywotny proces legislacyjny ze strony Stolicy Apostolskiej i poszczególnych Konferencji Biskupów²

1 Por. Sobór Watykański II, Lumen gentium. Konstytucja dogmatyczna o Kościele, 21.11.1964, w: Sobór Watykański II, Konstytucje, Dekrety, Deklaracje, Poznań 2002 (dalej: KK), n. 29; por. także, P. Małek, Odnowiona struktura posługi diakona wświetle pasterskiej władzy biskupa i prezbitera według nauki Soboru Watykańskiego II, Kraków 2008, s. 6.

2 Por. R. Selejdak, Zarys historyczny diakonatu stałego, Częstochowa 1998, s. 28-39; tenże, Diakonat stały w świetle Biblii i historii Kościoła, Częstochowa 2002, s. 113-116; tenże, Tożsamość, duchowość, formacja i posługa diakonów stałych, Częstochowa 2003, s. 7-8; tenże, Diakonat stały w świetle dokumentów Soboru Watykańskiego II, posoborowego Urzędu Nauczycielskiego Kościoła i narodowych «Rationes institutionis diaconorum permanentium», Warszawa 2010, s. 17. 
Według Dyrektorium o posłudze i życiu diakonów stałych, podstawą statusu zarówno teologicznego jak i prawnego diakona jest jego konsekracja i misja ${ }^{3}$.

\section{Wprowadzenie diakonatu stałego w strukturę hierarchiczną Kościoła lokalnego}

O wprowadzeniu diakonatu, jako właściwego i stałego stopnia hierarchii w danym kraju, decyduje jego Konferencja Episkopatu, po wcześniejszym otrzymaniu zgody Papieża ${ }^{4}$.

Konferencje Biskupów posiadają też prawo do określenia, przez uzupełniające przepisy, norm dotyczących obowiązku codziennego odmawiania Liturgii Godzinn', wieku wymaganego do przyjęcia święceń diakonatu ${ }^{6}$, formacji ${ }^{7}$ oraz utrzymania diakonów ${ }^{8}$.

Są one też zobowiązane do przedstawienia własnych Rationes institutionis diaconorum permanentium $\mathrm{w}$ celu rozpatrzenia i zatwierdzenia przez Stolicę Apostolską ${ }^{9}$. Normy opracowane przez Konferencje Biskupów winny dotyczyć różnych grup diakonów stałych: młodszych, starszych wiekiem, celibatariuszy, żonatych, wdowców, członków Instytutów życia konsekrowanego i Stowarzyszeń życia apostolskiego $^{10}$.

\subsection{Diakonat stały w diecezjach}

Należy podkreślić, iż przywrócenie diakonatu stałego w danym kraju wcale nie zobowiązuje do przywrócenia go we wszystkich diecezjach. Decyzja taka należy zawsze do danego biskupa diecezjalnego. Może

3 Por. Kongregacja ds. Duchowieństwa, Dyrektorium o posłudze i życiu diakonów stałych, 22.02.1998, Watykan 1998 (dalej: DPŻDS), n. 1.

4 Por. Kongregacja Edukacji Katolickiej, Wytyczne dotyczące formacji diakonów stałych, 22.02.1998, Watykan 1998 (dalej: WDFDS), n. 13.

5 Por. Kodeks Prawa Kanonicznego, Poznań 1984 (dalej: KPK), kan. $276 \$ 2$, 3.

6 Por. KPK, kan. $1031 \S 3$.

7 Por. tamże, kan. 236.

8 Por. tamże, kan. $281 \$ 3$.

9 Por. WDFDS, n. 13-15.

10 Por. tamże, n. 36-39. 
on ją podjąć po wysłuchaniu opinii Rady Kapłańskiej i Diecezjalnej Rady Duszpasterskiej oraz po uwzględnieniu konkretnych potrzeb i specyficznej sytuacji swojego Kościoła partykularnego. W przypadku wprowadzenia diakonatu stałego, biskup diecezjalny jest zobowiązany do zatroszczenia się o przeprowadzenie odpowiedniej katechezy, ułatwiającej osobom świeckim, kapłanom oraz zakonnikom zrozumienie sensu i roli posługi diakona stałego. Zobowiązany jest też do stworzenia niezbędnych struktur formacyjnych, nominacji odpowiednich współpracowników, którzy będą go wspomagali, odpowiadając bezpośrednio za formację. W zależności od okoliczności, biskup może powierzyć formację swoich kandydatów strukturom formacyjnym innych diecezji, regionalnym lub krajowym.

Ponadto, biskup diecezjalny, opierając się na Ratio narodowym, powinien podjąć odpowiednie wysiłki zmierzające do zredagowania i okresowego uaktualniania specjalnego regulaminu diecezjalnego, zawierającego szczegółowe przepisy dotyczące diakonów stałych ${ }^{11}$.

\subsection{Diakonat stały w Instytutach życia konsekrowanego i Stowarzyszeń życia apostolskiego}

Ustanowienie diakonatu stałego dla członków Instytutów życia konsekrowanego i Stowarzyszeń życia apostolskiego jest określone przez normy Motu proprio Sacrum diaconatus ordinem. Ustala on, że „ustanowienie stałego diakonatu dla zakonników jest prawem zarezerwowanym wyłącznie Stolicy Świętej, do której należy rozpatrzenie i zatwierdzenie opinii kapituł generalnych podjętych w tej materii"12. Zgodnie z tym co zostało powiedziane - kontynuuje dokument - „należy rozporządzenie to odnieść również do członków innych instytutów, którzy zobowiązali się do życia według rad ewangelicznych"13.

\footnotetext{
11 Por. tamże, n. 16.

12 Paweł VI, Motu proprio Sacrum diaconatus ordinem, 18.06.1967, AAS 59 (1967) 703.

13 Tamże, VII, 35, AAS 59 (1967) 704.
} 
Instytut lub Stowarzyszenie otrzymujące prawo przywrócenia diakonatu stałego jest zobowiązane do zapewnienia formacji ludzkiej, duchowej, intelektualnej i duszpasterskiej swoim kandydatom. Winny więc podjąć wysiłek, aby przygotować własny program formacyjny, odzwierciedlający właściwy sobie charyzmat i duchowość oraz odpowiadający wskazaniom Ratio fundamentalis institutionis diaconorum permanentium, szczególnie jeśli chodzi o formację intelektualną i duszpasterską. Następnie, taki program powinien być poddany do rozpatrzenia i zatwierdzenia, w zależności od kompetencji, Kongregacji Instytutów Życia Konsekrowanego i Stowarzyszeń Życia Apostolskiego, Kongregacji Ewangelizacji Narodów lub Kongregacji Kościołów Wschodnich. Właściwa Kongregacja, po zasięgnięciu opinii Kongregacji ds. Duchowieństwa, w tym co dotyczy formacji intelektualnej, zatwierdza dany program najpierw ad experimentum, a potem na określony czas, tak by były umożliwione okresowe rewizje ${ }^{14}$.

\section{Kandydaci do diakonatu stałego}

\subsection{Rozeznanie przez Kościół zdatności kandydata}

Należy zauważyć, że w przypadku powołania do urzędu kościelnego, oprócz wezwania Bożego i odpowiedzi człowieka, istnieje jeszcze inny, istotny element powołania. Jest nim wezwanie publiczne Kościoła, streszczające się w słowach: „Vocari a Deo dicuntur qui a legitimis Ecclesiae ministris vocantur" ${ }^{\prime 15}$. Wyrażenia tego nie należy rozumieć w znaczeniu tylko prawnym, które wskazywałoby na władzę kościelną jakby wzywającą człowieka do podjęcia określonego powołania, ale w znaczeniu sakramentalnym, interpretującym powołującą władzę kościelną, jako znak i narzędzie osobistej interwencji Boga realizującej się poprzez nałożenie rąk. W takiej perspektywie każde

\footnotetext{
14 Por. WDFDS, n. 17; Benedykt XVI, Motu proprio Ministrorum institutio, 16.01.2013, Art. 4 i 5, AAS 105 (2013) 134-135.

15 Catechismus ex decreto Concilii Tridentini ad Parochos, Torino 1914, cz. II, rozdz. 7, n. 3, s. 288.
} 
wybranie wyraża natchnienie i reprezentuje wybór Boży. Rozeznanie Kościoła jest zatem decydujące w wyborze powołania, tym bardziej ze względu na jego znaczenie kościelne, jako wybór powołania do urzędu święceń. To rozeznanie musi być bardzo uważne ${ }^{16}$. Ponadto musi być przeprowadzone według obiektywnych kryteriów, mających na względzie zarówno bogatą tradycję Kościoła, jak i aktualne potrzeby duszpasterskie. Przy rozeznaniu powołania do diakonatu stałego należy więc wziąć pod uwagę tak wymagania o charakterze ogólnym, jak i odnoszącym się do konkretnej sytuacji życiowej ${ }^{17}$.

\subsection{Przymioty i wymagania o charakterze ogólnym}

2.2.1. Przymioty i wymagania wynikające z Kodeksu Prawa Kanonicznego

Obowiązujący dziś Kodeks Prawa Kanonicznego stanowi: „Do święceń należy dopuszczać jedynie tych, którzy - według roztropnej oceny własnego biskupa albo kompetentnego przełożonego wyższego - po rozważeniu wszystkich okoliczności, mają nieskażoną wiarę, kierują się prawidłową intencją, posiadają wymaganą wiedzę, cieszą się dobrą opinią, mają nienaganne obyczaje, wypróbowane cnoty, jak również inne przymioty fizyczne i psychiczne odpowiadające przyjmowanemu święceniu"18.

Według Kodeksu Prawa Kanonicznego do diakonatu stałego mogą zostać dopuszczeni mężczyźni ochrzczeni ${ }^{19}$ i bierzmowani $^{20}$, zarówno celibatariusze, jak i mężczyźni żonaci oraz wdowcy. Kandydaci mogą pochodzić ze wszystkich środowisk społecznych i wykonywać jakąkolwiek pracę lub działalność zawodową, o ile nie będzie ona

\footnotetext{
16 Por. Jan Paweł II, Adhortacja apostolska Ecclesia in America, 22.01.1999, n. 42; R. Selejdak, Diakonat stały w świetle dokumentów Soboru Watykańskiego II, posoborowego Urzędu Nauczycielskiego Kościoła i narodowych «Rationes institutionis diaconorum permanentium", dz. cyt., s. 147.

17 Por. WDFDS, n. 29.

18 KPK, kan. 1029; por. także, kan. 1051, $1^{\circ}$.

19 Por. tamże, kan. 1024 i 1050, $3^{\circ}$.

20 Por. tamże, kan. 1033 i 1050, 3․
} 
uznana za niewłaściwą dla urzędu diakona, w świetle norm Kościoła i roztropnej oceny własnego ordynariusza ${ }^{21}$.

\subsubsection{Wiek kandydata}

W Konstytucji dogmatycznej o Kościele Lumen gentium występuje stwierdzenie, że: „Za zgodą Biskupa Rzymu będzie można udzielać takiego [stałego] diakonatu dojrzałym mężczyznom, również żyjącym w stanie małżeńskim, a także zdatnym do tego młodzieńcom, dla których jednak powinien pozostać w mocy obowiązek celibatu” 22 .

Wyjaśnienie terminu „mężczyzna dojrzały” znajduje się w Motu proprio Pawła VI Sacrum diaconatus ordinem. Dokument ten operuje pojęciem „wieku poźniejszego”, którym jest ukończone 35 lat życia ${ }^{23}$.

Podobne wymaganie stawia Kodeks Prawa Kanonicznego, kiedy ustala dolną granicę wieku kandydata. Kan. 1031 \$ 2 stanowi, iż kandydat do stałego diakonatu związany małżeństwem może być dopuszczony do tych święceń nie wcześniej, jak po ukończeniu przynajmniej trzydziestego piątego roku życia ${ }^{24}$.

Jednocześnie Kodeks dodaje, że Konferencje Episkopatu mają prawo wydać zarządzenie, mocą którego zostaje podwyższony wymagany wiek do diakonatu stałego ${ }^{25}$. Ponadto zarządza, iż dyspensa ponad rok od wieku, wymaganego zgodnie $\mathrm{z} \$ 2$ kan. 1031, jest zarezerwowana Stolicy Apostolskiej ${ }^{26}$.

Zadaniem J. Weiera nie należy tych rozporządzeń traktować w sensie absolutnym. Na potwierdzenie tego przywołuje rację, która w Motu proprio Sacrum diaconatus ordinem zdaje się wyjaśniać wyznaczoną

\footnotetext{
21 Por. tamże, kan. $285 \$ 1$.

22 KK, n. 29 b.

23 Por. Paweł VI, Motu proprio Sacrum diaconatus ordinem, III, 12, AAS 59 (1967) 700; por. także, M. Marczewski, Diakonat stały w dokumentach Soboru Watykańskiego II i posoborowego prawodawstwa Kościoła Powszechnego, RT 40 (1993) 6, s. 141.

24 Por. T. Rincón-Pérez, El orden de los clérigos o ministros sagrados, Pamplona 2009, s. 349.

25 Por. KPK, kan. $1031 \S 3$.

26 Por. tamże, kan. $1031 \S 4$.
} 
granicę wieku, a mianowicie, że nikt nie może być powołany do diakonatu, gdy nie zjednał sobie dobrej opinii duchowieństwa i wiernych długotrwałym przykładem prawdziwie chrześcijańskiego życia, nieskazitelnością obyczajów i usposobieniem skłonnym do posługiwania. J. Weier powołuje się ponadto na reskrypt Kongregacji Kultu Bożego i Dyscypliny Sakramentów z 28 marca 1981 roku, wymagający od kandydata żonatego dłuższego niż pięć lat pożycia małżeńskiego. W istocie chodzi o zadośćuczynienie istniejącym w Kościele już od czasów apostolskich wymaganiom potwierdzającym chrześcijańskie prowadzenie domu (por. $1 \mathrm{Tm} 3,10-12)^{27}$.

W tym kontekście zrozumiałym jest, iż narodowe Rationes institutionis diaconorum permanentium, wymagają od kandydatów żonatych, aby byli po przynajmniej pięciu latach małżeństwa ${ }^{28}$.

Dla nieżonatego kandydata do diakonatu stałego, określanego w soborowym dokumencie mianem „młodzieńca”, Motu proprio Sacrum diaconatus ordinem wyraźnie zastrzega, że „diakonat stały nie powinien być udzielany przed skończonym 25 rokiem życia”29. Ten sam dokument dodaje, że Konferencja Biskupów może określić wyższy wiek ${ }^{30}$. Kodeks Prawa Kanonicznego utrzymał w mocy powyższe postanowienie Motu proprio Pawła VI ${ }^{31}$.

Wszystkie wspomniane dokumenty określają dolną granicę wieku kandydata do święceń diakońskich. Nic nie mówią natomiast o granicy górnej, powyżej której nie należy udzielać święceń.

Cytowany J. Weier zwraca uwagę na praktykę partykularnych Kościołów krajów niemieckojęzycznych w tym względzie. Podaje on,

\footnotetext{
27 Por. J. Weier, Der ständige Diakon im Recht der lateinischen Kirche unter besonderer Berücksichtigung der Rechtslage in der Bundesrepublik Deutschland, Essen 1989, s. 40.

28 Por. T. Rincón-Pérez, El orden de los clérigos o ministros sagrados, dz. cyt., s. 349.

29 Paweł VI, Motu proprio Sacrum diaconatus ordinem, II, 5, AAS 59 (1967) 699; por. także, M. Marczewski, Diakonat stały w dokumentach Soboru Watykańskiego II i posoborowego prawodawstwa Kościoła Powszechnego, art. cyt., s. 142.

30 Paweł VI, Motu proprio Sacrum diaconatus ordinem, II, 5, AAS 59 (1967) 699.

31 Por. KPK, kan. $1031 \$ 2$; por. także, T. Rincón-Pérez, El orden de los clérigos o ministros sagrados, dz. cyt., s. 349.
} 
że w Niemczech, w diecezji Aachen górną granicę dopuszczenia do podjęcia kształcenia przygotowującego do otrzymania święceń wyznaczono na lat pięćdziesiąt dla kandydata na diakona stałego, który miałby pełnić swą posługę przy zachowaniu zawodu świeckiego. Dla kandydata, który miałby być zatrudniony na etacie diakona stałego w diecezji górną granicę wyznaczono na lat czterdzieści. W diecezji Hildesheim, stosownie do zaznaczonego wyżej charakteru posługi, wyznaczono granicę czterdziestu pięciu i czterdziestu lat. W diecezji mogunckiej wyznaczono pięćdziesiąt pięć i czterdzieści pięć lat, a $\mathrm{w}$ archidiecezji Freiburg, pięćdziesiąt pięć lat. Podobnie postanowiono w diecezji salzburskiej w Austrii ${ }^{32}$.

Należy jednak zaznaczyć, że powyższe rozstrzygnięcia dotyczące górnej granicy wieku wydają się być co najmniej dyskusyjne. Rację zdaje się mieć Weier, gdy przywołuje doświadczenie i stwierdza, że „wielu diakonów, którzy ukończyli 65 rok życia i w związku z tym przestali wykonywać swój zawód świecki, mogą wiele pomóc Kościołowi i ludziom"33.

\subsubsection{Nieprawidłowości i przeszkody}

Kandydaci do diakonatu muszą być wolni od nieprawidłowości i przeszkód, o których mowa w kanonach 1040-1042 Kodeksu Prawa Kanonicznego ${ }^{34}$.

32 Por. J. Weier, Der ständige Diakon im Recht der lateinischen Kirche, dz. cyt., s. 42-43; por. także, M. Marczewski, Diakonat stały w dokumentach Soboru Watykańskiego II i posoborowego prawodawstwa Kościoła Powszechnego, art. cyt., s. 142.

${ }^{33}$ J. Weier, Der ständige Diakon im Recht der lateinischen Kirche, dz. cyt., s. 43; por. także, M. Marczewski, Diakonat stały w dokumentach Soboru Watykańskiego II i posoborowego prawodawstwa Kościoła Powszechnego, art. cyt., s. 142; tenże, Diakonat, dz. cyt., s. 86-87.

${ }^{34}$ KPK, kan. 1040-1042. Nieprawidłowościami (stałymi przeszkodami) wyliczonymi w kan. 1041 są: 1) jakakolwiek forma amencji lub inna choroba psychiczna, na wskutek której - po zasięgnięciu opinii biegłych - kandydat jest uważany za niezdolnego do właściwego wykonywania posługi; 2) przestępstwo apostazji, herezji lub schizmy; 3) usiłowanie zawarcia małżeństwa, nawet tylko cywilnego; 4) dobrowolne zabójstwo albo spędzenie płodu, gdy skutek nastąpił; 5) poważne i z rozmysłem zranienie siebie lub kogoś innego albo usiłowanie odebrania sobie życia; 6) bezprawne wykonywanie 


\subsection{Przymioty związane ze stanem życia kandydata}

Wytyczne dotyczące formacji diakonów stałych podkreślają, iż kandydaci do diakonatu, oprócz przymiotów wymaganych przez Kodeks Prawa Kanonicznego oraz posługę diakońską, winni posiadać również takie, które odpowiadają ich zróżnicowanemu stanowi życia. Przymioty te mają gwarantować w przyszłości owocne realizowanie przez diakonów ich powołania ${ }^{35}$.

\subsubsection{Celibatariusze}

Papież Paweł VI przypomina, iż: „Zgodnie z prawem Kościoła, potwierdzonym przez sam Sobór Watykański II, ci którzy w młodym wieku zostali powołani do diakonatu są zobowiązani do życia w celibacie"36. Prawo to w sposób szczególny odpowiada posłudze diakońskiej, którą zobowiązali się dobrowolnie podjąć obdarzeni tym charyzmatem.

Diakon stały celibatariusz nadaje wspomnianej posłudze pewne specyficzne akcenty. Sakramentalne utożsamianie się z Chrystusem zostaje istotnie włączone w kontekst serca niepodzielnego, to jest wyboru oblubieńczego, wyłącznego, uroczystego i całkowitego jedynej i najwyższej Miłości. Kościół zaś może liczyć na pełną dyspozycyjność diakona w pełnieniu posługi ${ }^{37}$.

\subsection{2. Żonaci}

W przypadku mężczyzn żonatych zaleca się, aby do diakonatu byli dopuszczeni ci, którzy żyjąc wiele lat w małżeństwie potwierdzili

aktu święceń. Zwykłymi przeszkodami wyliczonymi w kan. 1042 są: 1) sprawowanie urzędu lub zarządu zakazanego duchownym; 2) bycie neofitą (dopóki według oceny ordynariusza kandydat nie został dostatecznie utwierdzony); por. także, WDFDS, n. 35.

35 Por. WDFDS, n. 36-39.

36 Paweł VI, Motu proprio Sacrum diaconatus ordinem, II, 4, AAS 59 (1967) 699; por. także, KK 29 b; KPK, kan. 1087; T. Rincón-Pérez, El orden de los clérigos o ministros sagrados, dz. cyt., s. 349.

37 Por. WDFDS, n. 36. 
umiejętność kierowania własnym domem oraz mają żonę i dzieci prowadzące życie prawdziwie chrześcijańskie ${ }^{38}$.

Kandydaci żonaci nie mogą być dopuszczeni do święceń bez wcześniejszej zgody żony ${ }^{39}$. Ponadto od żony wymaga się, aby cechowała się prawością chrześcijańską i naturalnymi przymiotami, które nie stanowiłyby przeszkody ani nie byłyby powodem wstydu dla posługi męża ${ }^{40}$.

Doświadczenie życiowe potwierdza, iż żona diakona stałego ma ogromny wpływ na kreowanie posługi męża oraz na jej sprawowanie pełne oddania. Podkreślił wyraźnie tę prawdę Jan Paweł II w swym przemówieniu do diakonów stałych Stanów Zjednoczonych Ameryki Północnej: „Wraz z całym Kościołem dziękuję Bogu za powołanie, które otrzymaliście i za waszą szczodrą odpowiedź. Dla większości z was, którzy żyjecie w małżeństwie, odpowiedź stała się możliwa dzięki miłości, wsparciu i współpracy waszych żon"41.

Należy zauważyć, że warunek postawiony wobec żony przyszłego diakona stałego w Motu proprio Sacrum diaconatus ordinem, wymagający od niej nienagannej moralności chrześcijańskiej i innych cech, które by nie utrudniały wypełniania przez męża jego obowiązków, nie został powtórzony w Kodeksie Prawa Kanonicznego z 1983 roku. Wydaje się to jednak oczywiste w świetle wymagań stawianych w kan. 1029 kandydatowi do święceń. Małżonkowie tworzą bowiem osobową wspólnotę, a atmosfera ich wspólnego i w pełni odpowiedzialnego

\footnotetext{
38 Por. Paweł VI, Motu proprio Sacrum diaconatus ordinem, III, 13, AAS 59 (1967) 700; WDFDS, n. 37; H. Denis - R. Schaller, Il diaconato nel mondo d'oggi, Milano 1968, s. 100-102.

39 Por. KPK, kan. 1050, $3^{\circ}$; T. Rincón-Pérez, El orden de los clérigos o ministros sagrados, dz. cyt., s. 349.

40 Por. Paweł VI, Motu proprio Sacrum diaconatus ordinem, III, 11, AAS 59 (1967) 700; KPK, kan. $1031 \S 2 ; 1050,3^{\circ}$; G. Mesnard, L'appel du Seigneur. Entretiens sur la vocation, Solesmes 1995, s. 177; E. Lodi, Le esigenze della diaconia secondo la lex orandi, Il diaconato in Italia 88 (1992), s. 25; G. Bellia, Arte o prassi del discernere?, Il diaconato in Italia 154 (2009), s. 6; E. Petrolino, Il diaconato permanente alla luce del Magistero post-conciliare, Seminarium 48 (2008) 4, s. 729-730.

41 Jan Paweł II, Discorso ai diaconi permanenti di Detroit, 19.09.1987, n. 1, w: Insegnamenti 10 (1987) 3, s. 654-655: tłum. własne.
} 
życia w znaczącym stopniu oddziaływuje na całość życia rodzinnego, zawodowego, a także realizowanej przez męża i ojca posługi. Wspomniał o tym Jan Paweł II: „On i jego żona wszedłszy we wspólnotę życia, są wezwani, by pomagać i służyć sobie nawzajem (por. Gaudium et spes, 48). Ich współpraca i jedność w sakramencie małżeństwa są tak intymne, że Kościół słusznie domaga się zgody żony przedtem, zanim mąż zostanie wyświęcony na diakona stałego (KPK, kan. 1031 $\$ 2$ ). Jak podkreśla aktualne Ratio dotyczące diakona stałego w Stanach Zjednoczonych, ubogacanie i pogłębianie wzajemnej, ofiarnej miłości pomiędzy mężem a żoną stanowi prawdopodobnie najbardziej znaczące zaangażowanie się żony diakona w publiczną służbę jej męża w Kościele (Wskazania, NCCB, 110). A dziś zwłaszcza nie jest to nieznaczna służba"42.

Prawodawca w kan. $1050,3^{\circ}$ przewiduje złożenie świadectwa zgody żony. Nie ulega wątpliwości, że chodzi tu o świadectwo pisemne, skoro kandydat przed dopuszczeniem do święceń powinien przedstawić własnemu biskupowi albo kompetentnemu przełożonemu wyższemu własnoręcznie sporządzone i podpisane oświadczenie, że z własnej woli i dobrowolnie przyjmuje święcenia ${ }^{43}$. Zdaniem Weiera żona mogłaby podpisać lub przyłączyć się do tej pisemnej prośby męża ${ }^{44}$.

\subsubsection{Wdowcy}

W świetle tradycyjnej dyscypliny kościelnej, po przyjęciu święceń, diakoni, również ci dopuszczeni w starszym wieku, nie mogą zawrzeć związku małżeńskiego ${ }^{45}$. Zasada ta dotyczy także diakonów, którzy zostali wdowcami ${ }^{46}$.

\footnotetext{
42 Tamże, n. 5, w: Insegnamenti 10 (1987) 3, s. 658: tłum. własne.

43 Por. KPK, kan. 1036.

44 Por. J. Weier, Der ständige Diakon im Recht der lateinischen Kirche, dz. cyt., s. 44 .

45 Por. Paweł VI, Motu proprio Sacrum diaconatus ordinem, III, 16, AAS 59 (1967) 701; tenże, Motu proprio Ad pascendum, 15.08.1972, VI, AAS 64 (1972) 539; KPK, kan. 1087.

${ }^{46}$ W celu otrzymania dyspensy od przeszkody określonej w kan. 1087, Pismo okólne Kongregacji ds. Kultu Bożego i Dyscypliny Sakramentów, Prot. N. 263/97
} 
Warunkiem dopuszczenia kandydatów-wdowców do święceń diakonatu jest zagwarantowanie przez nich lub wykazanie się gotowością zapewnienia odpowiedniej opieki rodzinnej i chrześcijańskiej swoim dzieciom $^{47}$.

\subsubsection{Członkowie Instytutów życia konsekrowanego}

i Stowarzyszeń życia apostolskiego

Diakoni stali, będący członkami Instytutów życia konsekrowanego lub Stowarzyszeń życia apostolskiego ${ }^{48}$, są powołani do ubogacenia ich posługi szczególnym charyzmatem, który otrzymali w określonej formie życia konsekrowanego. Istotnie, ich działalność duszpasterska, choć pod jurysdykcją ordynariusza miejsca ${ }^{49}$, winna odznaczać się cechami charakterystycznymi ich życia zakonnego lub konsekrowanego. Stąd są oni wezwani do podjęcia wysiłków mających na celu zharmonizowanie powołania zakonnego, czy też życia konsekrowanego, z powołaniem ministerialnym diakona i wnieść swój oryginalny wkład do misji Kościoła ${ }^{50}$.

z dnia 6 czerwca 1997 roku przewiduje, iż jest wystarczające zaistnienie tylko jednej z następujących okoliczności: znaczny i udokumentowany pożytek ze służby diakona w diecezji do której należy; obecność małych dzieci potrzebujących matki; obecność rodziców, bądź teściów, w podeszłym wieku, wymagających opieki (n. 8). Rozporządzenie to znosi wcześniejsze zawarte w Piśmie okólnym tejże Kongregacji, Prot. N. 2006/93, które stanowiło, iż aby otrzymać wspomnianą dyspensę musiały zaistnieć jednocześnie cztery okoliczności zweryfikowane i potwierdzone przez ordynariusza miejsca: a) potrzeba posługi diakona w diecezji; b) obecność małych dzieci, wymagających opieki; c) obecność rodziców w zaawansowanym wieku, wymagających również opieki; d) słabe zdrowie diakona. Por. także, A. Borras, Les effets canoniques de l'ordination diaconale, RTL 28 (1997), s. 469-470 ; A. Borras B. Pottier, La grazia del diaconato. Questioni attuali a proposito del diaconato latino, Assi 2005, s. 130-131 ; T. Rincón-Pérez, El orden de los clérigos o ministros sagrados, dz. cyt., s. 359-359.

47 Por. WDFDS, n. 38.

48 Por. Paweł VI, Motu proprio Sacrum diaconatus ordinem, VII, 32-35, AAS 59 (1967) 703-704.

49 Por. tenże, List apostolski Ecclesiae sanctae, 8.06.1966, I, 25, § 1, AAS 58 (1966) 770.

50 Por. WDFDS, n. 39. 


\section{Inkardynacja}

Diakoni są duchownymi, a zatem podlegają przepisom prawa kanonicznego określającym zasady inkardynacji ${ }^{51}$. Zgonie z kan. 265 KPK: „Każdy duchowny powinien być inkardynowany do jakiegoś Kościoła partykularnego albo do prałatury personalnej, albo do jakiegoś instytutu życia konsekrowanego lub do jakiegoś stowarzyszenia [...], tak, że nie może być duchownych nikomu nie podlegających czyli tułaczy”. Kanon 266 stanowi: „Przyjmujący diakonat staje się duchownym i zostaje inkardynowany do Kościoła partykularnego lub prałatury personalnej, dla których posługi został promowany"52; „Członek instytutu zakonnego po ślubach wieczystych albo członek kleryckiego stowarzyszenia życia apostolskiego definitywnie do niego włączony, przyjmując diakonat zostaje jako duchowny inkardynowany do tegoż instytutu lub stowarzyszenia, chyba że w odniesieniu do stowarzyszeń co innego postanawiają konstytucje”53; „Członek instytutu świeckiego przez przyjęcie diakonatu zostaje inkardynowany do Kościoła partykularnego, dla posługi którego został promowany, chyba że na mocy zezwolenia Stolicy Apostolskiej jest inkardynowany do samego instytutu" 54 .

Trwała więź diakona ze wspólnotą wiernych dokonana przez inkardynację może ulec zmianie przez ekskardynację i inkardynację

\footnotetext{
51 Por. KPK, kan. 265-172; Paweł VI, Motu proprio Ad pascendum, IX, AAS 64 (1972) 540; J. Dyduch, Diakonat stały w świetle dokumentów Stolicy Apostolskiej, PK 42 (1999) 1-2, s. 61; H. Schwendenwein, Der ständige Diakon, w: Handbuch des katholischen Kirchenrechts, red. J. Listl - H. Müller - H. Schmitz, Regensburg 1983, s. 229; T. Rincón-Pérez, El orden de los clérigos o ministros sagrados, dz. cyt., s. $354-355$.

52 KPK, kan. $266 \$ 1$.

53 Tamże, kan. $266 \$ 2$.

54 WDFDS, n. 8; DPŻDS, n. 2; por. J. Dyduch, Diakonat stały w świetle dokumentów Stolicy Apostolskiej, art. cyt., s. 61; J. Weier, Der ständige Diakon im Recht der lateinischen Kirche unter besonderer Berücksichtigung der Rechtslage in der Bundesrepublik Deutschland, dz. cyt., s. 69; H. Schmitz, Fragen der Inkardinationsrechtes, w: Ecclesia et Ius, red. K von Siepen - J. Weitzel - P. Wirth, Freiburg-Basel-Wien-Frankfurt a. M. 1996, s. 152.
} 
do nowej wspólnoty ${ }^{55}$. Ponadto diakon może pełnić służbę w innej diecezji niż diecezja inkardynacji, po uzyskaniu zgody obu biskupów i zawarciu między nimi odpowiedniej umowy ${ }^{56}$.

Według Dyrektorium o posłudze i życiu diakonów stałych, biskupi winni popierać diakonów swojej diecezji pragnących oddać się, czy to w formie stałej czy na określony czas, do dyspozycji Kościołów odczuwających brak duchowieństwa, oraz diakonów chcących poświęcić się, po uprzednim i odpowiednim przygotowaniu, misjom ad gentes. Niezbędne formalności w tym względzie powinny być uregulowane odpowiednią umową zawartą przez zainteresowanych biskupów ${ }^{57}$.

Papież Paweł VI zachęca wszystkich biskupów do okazywania właściwej troski diakonom swojej diecezji ${ }^{58}$. Osobiście lub za pośrednictwem delegowanego przez siebie kapłana powinni oni udzielić pomocy tym, którzy na wskutek swojej sytuacji życiowej znaleźli się w szczególnych trudnościach.

Jeśli chodzi o diakona inkardynowanego do Instytutu życia konsekrowanego czy Stowarzyszenia życia apostolskiego, to ma on wykonywać swoją posługę pod władzą biskupa w tym wszystkim, co odnosi się do duszpasterstwa, sprawowania publicznego kultu Bożego i dzieł apostolatu. Jednocześnie podlega on własnym przełożonym w dziedzinie ich kompetencji oraz prawu własnemu wspólnoty, do której przynależy ${ }^{59}$. W przypadku przeniesienia do wspólnoty znajdującej się na terenie innej diecezji, przełożony jest zobowiązany przedstawić diakona miejscowemu Ordynariuszowi w celu uzyskania od niego pozwolenia na wykonywanie posługi. Zakres tej posługi zostanie ustalony w rozważnej umowie ${ }^{60}$.

\footnotetext{
55 Por. KPK, kan. 267.

56 Por. tamże, kan. 271; DPŻDS, n. 3; T. Rincón-Pérez, El orden de los clérigos o ministros sagrados, dz. cyt., s. 356.

57 Por. DPŻDS, n. 3.

58 Por. Paweł VI, Motu proprio Sacrum diaconatus ordinem, VII, 30, AAS 59 (1967) 703.

59 Por. KPK, kan. $678 § 1-3$; kan. 715, 738; por. także, Paweł VI, Motu proprio Sacrum diaconatus ordinem, VII, 33-35, AAS 59 (1967) 704 ; DPŻDS, n. 4.

60 Por. DPŻDS, n. 4.
} 
Specyficzne powołanie i przygotowanie diakona stałego zakłada wytrwanie w przyjętych święceniach. Ewentualne przejście diakonów stałych nieżonatych lub wdowców do prezbiteratu powinno być rzadkim wyjątkiem, możliwym tylko wówczas, gdy zaistnieją szczególne i ważne przyczyny. Decyzja o dopuszczeniu do stanu kapłańskiego należy wtedy do właściwego biskupa diecezjalnego, jeżeli nie zachodzą inne nieprawidłowości zarezerwowane Stolicy Apostolskiej ${ }^{61}$. $\mathrm{Z}$ uwagi jednak na wyjątkowość tego rodzaju przejścia zaleca się, aby biskup skonsultował się wcześniej z Kongregacją ds. Duchowieństwa odnośnie programu przygotowania intelektualnego i duszpasterskiego diakona oraz jego zdatnosći do ewentualnego podjęcia posługi kapłańskiej ${ }^{62}$.

\section{Obowiązki i prawa diakona stałego}

Diakoni, mocą otrzymanych święceń, są zjednoczeni między sobą we wspólnocie sakramentalnej. Pod władzą biskupa, w łączności z Papieżem, podejmują dzieło budowania Ciała Chrystusa ${ }^{63}$.

Różne funkcje kościelne diakoni wypełniają także w łączności z prezbiterami: „Wszystkie te funkcje winny być wykonywane w doskonałej łączności z biskupem i jego prezbiterium, czyli pod władzą biskupa i kapłana, którzy w danym miejscu prowadzą duszpasterstwo"64.

Biskup miejsca jest zobowiązany do animowania diakonów działających w diecezji „duchem wspólnoty”. Taki duch ma ich ochraniać przed pokusą tworzenia „,korporacjonizmu”, który w przeszłości w dużym stopniu przyczynił się do zniknięcia diakonatu stałego ${ }^{65}$.

\footnotetext{
61 Por. tamże, n. 5; por. także, Sekretariat Stanu, List do Kardynała Prefekta Kongregacji ds. Kultu Bożego i Dyscypliny Sakramentów, Prot. N. 122.735, 3.01.1984.

${ }^{62}$ Por. DPŻDS, n. 5; Benedykt XVI, Motu proprio Ministrorum institutio, Art. 4 i 5, AAS 105 (2013) 134-135; T. Rincón-Pérez, El orden de los clérigos o ministros sagrados, dz. cyt., s. 355.

63 Por. Paweł VI, Motu proprio Sacrum diaconatus ordinem, V, 23, AAS 59 (1967) 702; DPŻDS, n. 6.

${ }^{64}$ Paweł VI, Motu proprio Sacrum diaconatus ordinem, V, 23, AAS 59 (1967) 702.

65 Por. DPŻDS, n. 6.
} 
Diakoni stali, jako przynależący do stanu duchownego ${ }^{66}$, związani są obowiązkami i prawami - określonymi w Kodeksie Prawa Kanonicznego w kanonach 273-289 - dotyczącymi duchownych, uwzględniając specyfikę, jaką w Kościele charakteryzuje się diakonat stały ${ }^{67}$.

Diakoni stali żonaci nie tracą praw i obowiązków właściwych zawartemu sakramentowi małżeństwa. Żyjąc w stanie małżeńskim mają przyczyniać się do budowania Ludu Bożego przez małżeństwo i rodzinę $e^{68}$; troszczyć się o chrześcijańskie wychowanie dzieci, zgodnie z nauką przekazywaną przez Kościół ${ }^{69}$; żyć zgodnie z naturą zawartego sakramentu małżeństwa i otrzymaną z niego łaską ${ }^{70}$; zabiegać o to wszystko czego wymaga wspólnota życia małżeńskiego ${ }^{71}$.

Z przynależności diakonów do stanu duchownego wynikają konkretne skutki prawne dotyczące małżeństwa. Diakoni, którzy przyjęli święcenia jako celibatariusze nie mogą ważnie zawrzeć małżeństwa ${ }^{72}$. W przypadku pozostawienia urzędu diakońskiego nie mogą zawrzeć związku małżeńskiego, jeśli wcześniej nie otrzymali dyspensy od przeszkody wynikającej ze święceń ${ }^{73}$ oraz dyspensy od obowiązku celibatu $^{74}$.

Podczas obrzędu święceń diakoni składają biskupowi przyrzeczenie szacunku i posłuszeństwa. Na wzór Jezusa, posłusznego Ojcu w najwyższym stopniu ${ }^{75}$, mają oni na Jego przykładzie opierać własne posłuszeństwo w słuchaniu ${ }^{76} \mathrm{i}$ w radykalnej dyspozycyjności ${ }^{77}$. Dlatego, przede wszystkim wobec Boga, są zobowiązani do

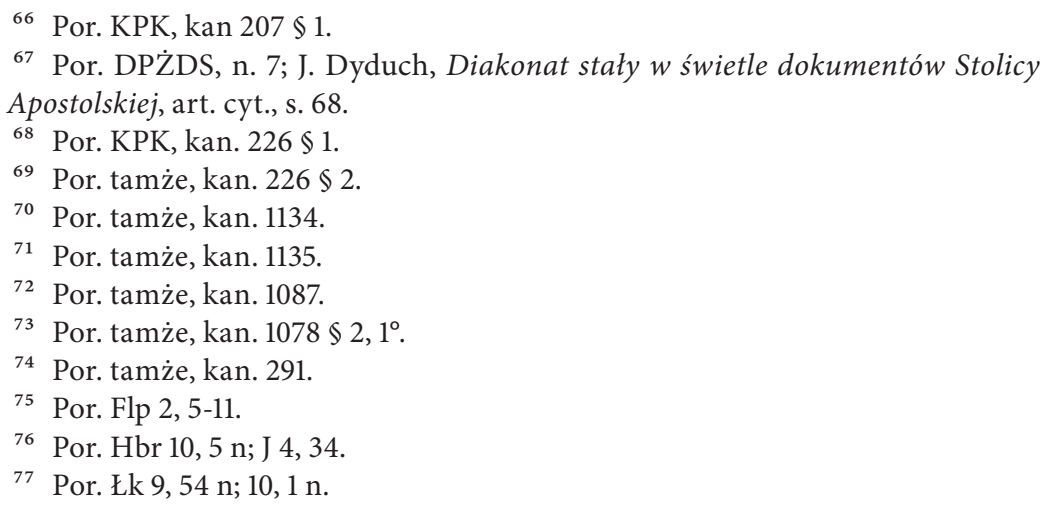


działania w całkowitej zgodzie z wolą biskupa. Takie zobowiązanie podejmują również wobec Kościoła, potrzebującego osób w pełni dyspozycyjnych ${ }^{78}$.

Diakoni, przeniknięci duchem pobożności, winni codziennie pogłębiać dar całkowitego poświęcania się tak, jak czynił to Jezus „aż do śmierci i to śmierci krzyżowej"79.

Taka wizja posłuszeństwa nie wyklucza w przyrzeczeniu, dokonanym podczas święceń, możliwości określania zakresu obowiązków nałożonych na diakonów, zgodnie z tym, co przewiduje prawo Kościoła: „Duchowni mają obowiązek, chyba że usprawiedliwia ich prawnie uznana przeszkoda, przyjąć i wiernie wypełnić zadania powierzone im przez własnego Ordynariusza"80.

Zakres posłuszeństwa i dyspozycyjności określa posługa diakońska oraz to wszystko, co łączy się z nią podmiotowo wprost i bezpośrednio ${ }^{81}$.

Biskup, w dekrecie nadania urzędu diakonowi określa zadania odpowiadające predyspozycjom osobistym, stanowi celibatariusza lub mającego rodzinę, formacji, wiekowi, oraz aspiracjom, które uzna za wartościowe duchowo. Ponadto określa zakres terytorialny lub personalny, w ramach którego ma być sprawowana posługa apostolska, z zaznaczeniem, czy będzie ona miała charakter czasowy czy stały i który z prezbiterów będzie odpowiedzialny za „cura animarum” ${ }^{82}$.

\footnotetext{
78 Jan Paweł II, Zarys duchowości diakona. Katecheza podczas Audiencji Generalnej, 20.10.1993, n. 2, OR, wyd. pol. 1 (1994), s. 41: „Jeśli ktoś odznacza się skłonnością do kontestacji lub opozycji wobec władzy, nie może odpowiednio wypełniać funkcji diakońskich. Święceń diakonatu można udzielić tylko tym, którzy wierzą w pasterską wartość misji biskupa i prezbitera i w pomoc Ducha Świętego, który ich prowadzi w działaniu i przy podejmowaniu decyzji. W szczególności należy jeszcze raz przypomnieć, że diakon powinien «przyrzec biskupowi cześć i posłuszeństwo» [...]. Służba diakona zwrócona jest również ku jego wspólnocie chrześcijańskiej i ku całemu Kościołowi, do którego powinien być głęboko przywiązany z racji swej misji i ustanowienia Bożego".

79 Flp 2, 8.

${ }^{80}$ KPK, kan. $274 \$ 2$.

81 Por. DPŻDS, n. 8.

82 Por. tamże.
} 
Diakoni, oprócz utrzymywania wzajemnej więzi braterstwa i modlitwy oraz współpracy między sobą, z kapłanami i biskupem, mają współdziałać z wiernymi świeckimi, wspierając ich misję w Kościele i świecie. Przez umiarkowany i prosty styl życia są powołani do dawania świadectwa o Chrystusie wobec świata ${ }^{83}$.

Diakoni stali nie są zobowiązani do noszenia stroju duchownego, z wyjątkiem członków Instytutów życia konsekrowanego i Stowarzyszeń życia apostolskiego, którzy winni dostosować się do tego, co zostało dla nich postanowione w Kodeksie Prawa Kanonicznego ${ }^{84}$.

W Polsce ustalono, że strojem diakona stałego jest odpowiedni, poważny strój świecki z przypiętą odznaką diakona stałego ${ }^{85}$.

Podczas pełnienia funkcji liturgicznych diakon winien używać stroju liturgicznego. O stroju liturgicznym diakona wzmiankuje już Synod w Kartaginie z 398 roku, który zaleca noszenie przez niego alby tempore oblationis et lectionis, stuły przewieszonej przez ramię na dalmatyce (tunice) ${ }^{86}$. Jako ubiór sakralny dalmatyka pierwszy raz jest widoczna na fresku $\mathrm{z}$ III wieku w rzymskich katakumbach Pryscylli. Fresk przedstawia konsekrację dziewic, w czasie której biskup jest ubrany w dalmatykę i penulę. Wcześniej dalmatyka była uważana za strój osób zamożnych i pełniących różne funkcje społeczne. W IV wieku papież Sylwester wręczył diakonom dalmatykę na znak specjalnych relacji z papieżem. Do XI wieku dalmatyka zachowała kolor biały, z czasem przybierała kolory używane w liturgii. Świadectwa z IX wieku dowodzą, że była ona noszona nie tylko przez diakonów, lecz także przez biskupów i prezbiterów pod ornatem. Z czasem dalmatyka stała się szatą noszoną przez diakona w czasie czynności liturgicznych ${ }^{87}$. Obecnie podczas sprawowania liturgii strój

\footnotetext{
${ }^{83}$ Por. tamże, n. 9.

${ }^{84}$ Por. tamże, n. 10; por. także, KPK, kan. 669.

85 Por. Konferencja Episkopatu Polski, Wytyczne dotyczace formacji, życia i posługi diakonów stałych w Polsce, 22.01.2004, w: Biblioteka „Niedzieli”, t. 157, Częstochowa 2004, n. 90.

86 Por. C. Traunecker, Koptyjska stuła diakońska, Vox Patrum 9 (1989) 17, s. 717.

87 Por. M. Righetti, Storia liturgica, t. I, Milano 1950, s. 506-507; P. Petryk, Święcenia diakonów, RT 49 (2002) 8, s. 159.
} 
diakona stanowi alba i dalmatyka w stosownym kolorze liturgicznym dnia, pasek i stuła ${ }^{88}$.

Diakoni stali mają prawo zrzeszania się między sobą celem wspierania i rozwijania własnego życia duchowego, wykonywania dzieł miłosierdzia, pobożności oraz realizacji innych celów, będących w pełnej zgodności z ich sakramentalną konsekracją i misją ${ }^{89}$.

Podobnie jak innym duchownym, diakonom stałym nie wolno zakładać, przynależeć czy działać w stowarzyszeniach lub jakichkolwiek grupach, także świeckich, jeśli byłoby to trudne do pogodzenia $z$ ich stanem duchownym albo utrudniałoby sumienne wykonywanie ich posługi. Zobowiązani są też do unikania wszelkich stowarzyszeń szkodzących pełnej jedności hierarchicznej Kościoła, przynoszących szkodę tożsamości diakońskiej i działających przeciw Kościołowi ${ }^{90}$.

Oprócz tego diakonom stałym nie wolno przynależeć do stowarzyszeń roszczących sobie prawo do reprezentowania ich na sposób korporacji lub związku zawodowego, do grup redukujących ich świętą posługę do zawodu lub rzemiosła świeckiego, a także do organizacji zmieniających w jakikolwiek sposób relacje pośrednie lub bezpośrednie, jakie powinni utrzymywać ze swoimi biskupami. Przynależność do takich stowarzyszeń jest zakazana, ponieważ działają one na szkodę wypełniania świętej posługi diakońskiej i wystawiają ją na ryzyko traktowania podrzędnego. Ponadto wprowadzają pewną dynamikę dialektyczną, przeciwstawiającą się świętym pasterzom, którzy mogliby być traktowani wyłącznie jako pracodawcy ${ }^{91}$.

W tym kontekście należy zauważyć, iż ewentualna działalność zawodowa diakona stałego ma głębokie i odmienne znaczenie od

\footnotetext{
88 Por. Wprowadzenie do Mszału Rzymskiego, Poznań 1986, n. 81 b, 300, 302; M. Gawlik - M. Marczewski, Dyrektorium o posłudze i życiu diakonów stałych, RT 46 (1999) 8, s. 207; D. Messina, I segni del celebrare e la simbolica diaconale, w: Dal tempio alla strada... la martyria della profezia. Corsi di formazione permanentne per Presbiteri e Diaconi, red. M. Russotto, t. IV, Palermo 2002-2003, s. 166-169.

89 Por. DPŻDS, n. 11.

90 Por. KPK, kan. $278 \$ 3$.

91 Por. DPŻDS, n. 11.
} 
tej, którą sprawuje wierny świecki ${ }^{92}$. W przypadku diakonów stałych praca zawodowa połączona jest ściśle z posługą. W wypełnianiu swojej misji winni oni nieustannie uświadamiać sobie, że są powołani do tego „aby czynić obecnym i aktywnym Kościół, w takich miejscach, gdzie jedynie przy ich pomocy stać się on może solą ziemi"93.

Dokumenty kościelne nie zakazują diakonom stałym przyjmowania i wykonywania zawodu czy urzędu świeckiego, ani angażowania się $\mathrm{w}$ administrację dobrami doczesnymi czy podejmowania pracy w urzędach publicznych. W przypadku działalności handlowej lub prowadzenia interesów, diakoni są zobowiązani do dania przykładu uczciwości i poprawności zawodowej.

Wspomniana działalność jest traktowana przez powszechne prawo kościelne w odmienny sposób niż w przypadku pozostałych duchownych. Przepisy zabraniające tych działań zostały wobec diakonów stałych uchylone, $\mathrm{z}$ tym, że sprawy te może inaczej normować prawodawstwo partykularne. Uchylenie to nie odnosi się do diakonów stałych przynależących do Instytutów życia konsekrowanego i Stowarzyszeń życia apostolskiego. Czynne zaangażowanie się w działalność partii politycznych i związków zawodowych może być dopuszczone jedynie wtedy, gdy wymaga tego obrona Kościoła i dobro wspólne obywateli. Diakonom zakazana jest jednak zdecydowanie współpraca z partiami i ruchami związkowymi opierającymi się na ideologiach, praktyce i koalicjach sprzecznych z doktryną katolicką ${ }^{94}$.

\footnotetext{
92 Por. Jan Paweł II, Discorso ai Vescovi dello Zaire in Visita „ad limina”, 30.04.1983, n. 4, w: Insegnamenti 6 (1983) 1, s. 1112-1113; Discorso ai diaconi permanenti in Italia, 16.03.1985, w: Insegnamenti 8 (1985) 1, s. 648-650; por. również, Discorso durante l'ordinazione di otto nuovi Vescovi a Kinshasa, 4.05.1980, n. 3-5, w: Insegnamenti 3 (1980) 1, s. 1111-1114; Catechesi durante l'Udienza Generale, 6.10.1993, w: Insegnamenti 16 (1993) 2, s. 951-955.

93 KK, n. 33; por. także, KPK, kan. 225.

94 Por. DPŻDS, n. 13; por. także, T. Rincón-Pérez, El orden de los clérigos o ministros sagrados, dz. cyt., s. 359-362.
} 
Diakoni, ażeby móc oddalić się z diecezji „na dłuższy czas”, zgodnie z przepisami prawa partykularnego, z zasady winni posiadać zezwolenie własnego ordynariusza lub wyższego przełożonego ${ }^{95}$.

Ponadto „powinni powstrzymywać się od tego wszystkiego, co wprost nie przystoi ich stanowi" ${ }^{96}$ lub co jest „obce” temu stanowi ${ }^{97}$.

Niezwykle delikatną sprawą jest uregulowanie utrzymania i ubezpieczenia diakonów stałych.

Diakoni za udzielanie sakramentów nie mogą domagać się niczego innego oprócz ofiar określonych przez kompetentną władzę kościelną ${ }^{98}$.

Pracujący zawodowo winni utrzymywać się z otrzymywanych wynagrodzen' ${ }^{9}$. Prawodawca nie ignoruje słów Pisma Świętego: „zasługuje robotnik na swoją zapłatę" (Łk 10,7) i „Tak też i Pan postanowił, ażeby z Ewangelii żyli ci, którzy głoszą Ewangelię" (1 Kor 9, 14). Jednakże, wspomnianych słów nie interpretuje jako prawa absolutnego i niezbywalnego. Już święty Paweł Apostoł zrzekł się prawa do wynagrodzenia za spełnianą posługę ewangelizacyjną i sam pracując troszczył się o swoje utrzymanie (por. 1 Kor 9, 12). Obowiązujące przepisy prawne w tym względzie biorą pod uwagę możliwości ekonomiczne Kościołów partykularnych i odmienność sytuacji w różnych krajach.

Diakoni zatrudnieni w pełnym wymiarze czasu w instytucjach kościelnych mają prawo do otrzymywania odpowiedniego wynagrodzenia i opieki społecznej ${ }^{100}$.

Sprawa sprawiedliwego wynagrodzenia inaczej kształtuje się w stosunku do diakonów żonatych, mających na utrzymaniu rodziny, niż w stosunku do diakonów celibatariuszy.

Odnośnie diakonów żonatych Kodeks Prawa Kanonicznego ustanawia, że: „Diakoni żonaci, którzy się całkowicie oddali kościelnej

95 Por. KPK, kan. $283 \$ 1$.

96 Tamże, kan. $285 \$ 1$.

97 Por. tamże, kan. $285 \$ 2$.

98 Por. tamże, kan. 848.

99 Por. Paweł VI, Motu proprio Sacrum diaconatus ordinem, IV, 21, AAS 59 (1967)

701; DPŻDS, n. 15.

${ }^{100}$ Por. DPŻDS, n. 16. 
posłudze, zasługują na wynagrodzenie wystarczające na ich utrzymanie oraz ich rodzin. Ci jednak, którzy otrzymują wynagrodzenie $\mathrm{z}$ racji świeckiego zawodu, który wykonują lub wykonywali, powinni z otrzymanych z tego dochodów zaspokajać potrzeby własne i swojej rodziny" ${ }^{101}$. Określenie wynagrodzenia „wystarczającego”, dokonuje się według takich kryteriów jak: sytuacja osobista szafarza, natura, miejsce i czas pełnionej posługi, potrzeby życiowe rodziny diakona jeśli jest żonaty, sprawiedliwe wynagrodzenie dla osób, które ewentualnie byłyby na jego służbie ${ }^{102}$.

Diakoni bezżenni, oddający się całkowicie kościelnej posłudze w diecezji i nie posiadający żadnego innego źródła utrzymania, mają prawo do wynagrodzenia zgodnie z zasadą ogólną ${ }^{103}$.

Opracowanie odpowiednich norm w tej materii jest zadaniem Konferencji Biskupów, z uwzględnieniem zasad sprawiedliwości, a czasem ewentualnych porozumień między Stolicą Apostolską i Konferencjami Biskupów z jednej strony, a rządami poszczególnych krajów z drugiej strony. W niektórych przypadkach konieczne są umowy między mającymi przyjąć święcenia diakonatu a diecezją ${ }^{104}$.

Prawo partykularne winno, między innymi ustalić poprzez stosowne przepisy, że jednostki i parafie korzystające z posługi diakona mają obowiązek zwrócić mu koszty związane z bieżącymi wydatkami, poniesionymi z tytułu sprawowanej posługi. Ponadto prawo partykularne może określić, jakie zobowiązania winna podjąć diecezja w stosunku do diakona, który bez winy zostałby pozbawiony pracy cywilnej. Stosownym jest także określenie ewentualnego zobowiązania ekonomicznego diecezji w stosunku do żony i dzieci zmarłego diakona ${ }^{105}$.

\footnotetext{
${ }^{101}$ KPK, kan. $281 \$ 3$; por. także, DPŻDS, n 19; T. Rincón-Pérez, El orden de los clérigos o ministros sagrados, dz. cyt., s. 363.

102 Por. DPŻDS, n. 16.

103 Por. KPK, kan. 281 \$1; DPŻDS, n. 17; por. także, T. Rincón-Pérez, El orden de los clérigos o ministros sagrados, dz. cyt., s. 363.

${ }^{104}$ Por. DPŻDS, n. 15-20.

105 Por. tamże, n. 20; por. także, T. Rincón-Pérez, El orden de los clérigos o ministros sagrados, dz. cyt., s. 363 .
} 
Opieka społeczna dla diakonów stałych, jeżeli nie zostało inaczej przewidziane, winna być powierzona właściwej instytucji ${ }^{106}$. Stąd biskup diecezjalny (przełożony zakonny) winien zatroszczyć się o należyte ubezpieczenie zdrowotne i społeczne diakonów i ich rodzin.

\section{Misja kanoniczna diakonów stałych}

Każdy diakon na mocy przyjętych święceń jest wezwany do sprawowania potrójnej diakonii: Słowa, liturgii i miłosierdzia. Według Jana Pawła II, te trzy zakresy posługi diakońskiej stanowią jedność w służbie dziełu zbawienia Bożego: „Jeżeli rozważymy głęboką naturę duchową tej diakonii, możemy lepiej dowartościować te trzy płaszczyzny posługi, tradycyjnie połączone $\mathrm{z}$ diakonatem, tj. posługą Słowu, posługą ołtarzowi i posługą miłości. Według okoliczności, pierwsza czy druga z nich może nadać szczególnej wartości indywidualnej pracy diakona, wszystkie zaś trzy posługi są nierozłączne $w$ całościowej służbie Bożego planu zbawczego"107.

Swobodne powierzanie poszczególnym diakonom urzędu kościelnego, jeśli prawo czegoś innego wprost nie postanawia, należy do biskupów diecezjalnych ${ }^{108}$, którzy przewodniczą i zarządzają Kościołami partykularnymi "jako zastępcy i legaci Chrystusa"109. W powierzaniu urzędu biskupi są zobowiązani do dokładnego rozważenia potrzeb pastoralnych oraz sytuacji osobistej, rodzinnej - w odniesieniu do żonatych - i zawodowej diakonów. Jest ogromnie ważne, aby diakoni, w zależności od swoich możliwości, mogli wykonywać w pełni posługę głoszenia Słowa Bożego, posługę liturgii i dzieła miłosierdzia. Należy jednocześnie unikać powierzania diakonom obowiązków drugorzędnych i tylko funkcji zastępczych, które mogą być wykonywane przez wiernych świeckich. Tylko w ten sposób diakoni

\footnotetext{
${ }^{106}$ Por. DPŻDS, n. 16; KPK, kan. $1274 \$ 2$.

107 Jan Paweł II, Discorso ai diaconi permanenti di Detroit, n. 3, w: Insegnamenti 10 (1987) 3, s. 656.

108 Por. KPK, kan. 157.

109 KK, n. 27.
} 
stali ukażą się w swojej prawdziwej tożsamości jako słudzy Chrystusa, a nie jako świeccy szczególnie zaangażowani w życie Kościoła.

Diakoni mogą spełniać swoją posługę zarówno na poziomie duszpasterstwa parafialnego jak i diecezjalnego.

Biskup może oddelegować diakonów do współpracy w duszpasterstwie w parafii powierzonej tylko samemu proboszczowi ${ }^{110}$ lub do służby duszpasterskiej w kilku parafiach, powierzonych in solidum jednemu lub kilku kapłanom ${ }^{111}$.

W przypadku uczestnictwa w służbie pasterskiej jednej parafii, w której z powodu małej ilości prezbiterów nie może ona cieszyć się bezpośrednią opieką proboszcza ${ }^{112}$, diakoni stali mają zawsze pierwszeństwo przed wiernymi nie posiadającymi święceń kapłańskich. Należy przy tym podkreślić, iż diakon $\mathrm{w}$ takich przypadkach jest jedynie współpracownikiem, zaś moderatorem jest kapłan, ponieważ tylko on jest „«właściwym pasterzem» i może otrzymać urząd «cura animarum» dla powierzonego sobie ludu"113.

Według Motu proprio Sacrum diaconatus ordinem Pawła VI, diakoni mogą być posłani przez proboszcza lub biskupa do kierowania rozproszonymi wspólnotami chrześcijańskimi ${ }^{114}$.

Zdaniem M. Marczewskiego ${ }^{115}$, stwierdzenie to od początku uznawano za kontrowersyjne. Użyty bowiem łaciński termin legitime regere nie był dotąd używany w języku prawnym. Wprawdzie w numerze 16 soborowego Dekretu o działalności misyjnej Kościoła Ad gentes divinitus mówi się o kierowaniu przez osoby świeckie „odległymi wspólnotami chrześcijańskimi”, to jednak użyto tam określenia moderare, które jest o wiele bardziej odpowiednie niż regere.

Sprzeciw wobec możliwości kierowania przez diakona parafią zgłaszał bezpośrednio wybitny teolog K. Rahner i pośrednio znany

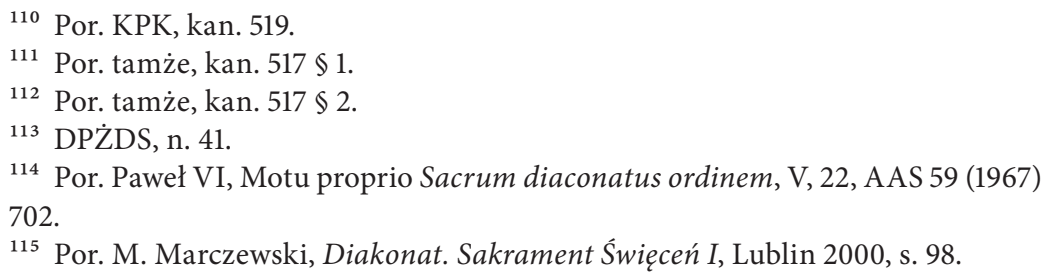


wiedeński pastoralista F. Klostermann. Pierwszy podkreślał, że jest to sprzeczne z przeznaczeniem diakona do służby, diakonii, którą ma spełniać i której ma dawać świadectwo ${ }^{116}$. Drugi natomiast zwrócił uwagę na to, że parafia ma prawo posiadania własnego prezbitera: „Każda pełna wspólnota parafialna [...] wymaga dla uznania jej jako wspólnoty przez hierarchię oraz do jej duchowego przewodnictwa przynajmniej jednego ordynowanego prezbitera [...]. Nie pomogą tu ani asystenci pastoralni, ani pomocnicy komunijni, ani diakoni, ani siostry zakonne. To prawda, że nie można z jednej strony redukować posługi kapłańskiej do sfery kultu, w tym do sprawowania Eucharystii, z drugiej jednak - to sprawowanie Eucharystii jest ukoronowaniem i szczytem duchowego przewodnictwa, bez którego nie tylko funkcja kierowania, lecz także i eucharystyczne świętowanie traci swe znaczenie. W konsekwencji powierzenie diakonowi lub świeckiemu, czy też zakonnicom posługi kierowania chrześcijańskimi wspólnotami prowadzi do rozdzielenia faktycznego kierowania wspólnotą od przewodniczenia Eucharystii i podzielenia pastoralnych założeń"117.

Wypośrodkowane rozwiązanie tej trudnej kwestii usiłuje podać Kodeks Prawa Kanonicznego. Przypomina on, że: „proboszcz jest własnym pasterzem zleconej sobie parafii" ${ }^{118}$. W przypadku zaś, gdy wymagają tego okoliczności, „gdyby [...] biskup diecezjalny doszedł do wniosku, że do współudziału w trosce o pasterzowanie parafią należy dopuścić diakona lub jakąś inną osobę nie mającą święceń kapłańskich, albo jakąś wspólnotę osób, to powinien ustanowić jakiegoś kapłana, który by posiadając władzę i uprawnienia proboszczowskie,

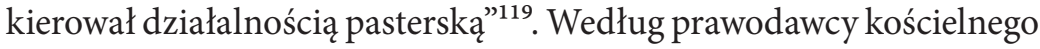
diakon z racji przyjętych święceń może być dopuszczony do udziału $\mathrm{w}$ trosce pasterskiej o parafię w zakresie własnego stopnia.

\footnotetext{
116 Por. K. Rahner, Teologie des Diakonats, w: Der Diakon. Ein Werkbuch für den deutschsprachigen Raum, red. A. Fischer - H. Kramer - H. Vorgrimler, Freiburg im Br. 1970, s. 33.

117 F. Klostermann, Die pastoralen Dienste heute. Priester und Laien im pastoralen Dienst, Linz-Wien-Passau 1980, s. 232-233.

118 KPK, kan. 519.

119 Tamże, kan. $517 \$ 2$.
} 
W normie tej opisana jest relacja posługi diakona do pasterskiej władzy biskupa i prezbitera. Diakoni na mocy przyjętych święceń wykonują zadania uświęcania, nauczania oraz rządzenia, ale zawsze spełniają je pod władzą biskupa i prezbitera. Z powodu braku kapłanów diakon może być dopuszczony do udziału w trosce pasterskiej o parafian, będąc wyznaczony do tego zadania przez biskupa. Swój udział w sprawowaniu troski wykonuje pod przewodnictwem prezbitera, który posiada władzę oraz uprawnienia proboszczowskie. Diakon nigdy nie może przejąć całej troski o parafię ${ }^{120}$. Prawodawca kościelny wyraźnie zaznacza, że temu, kto nie otrzymał święceń kapłańskich, nie można ważnie nadać urzędu związanego z pełnym duszpasterstwem, do wykonywania którego potrzebne jest posiadanie władzy kapłańskiej ${ }^{121}$.Z tego też powodu, aby ktoś mógł ważnie zostać proboszczem, musi posiadać święcenia prezbiteratu ${ }^{122}$.

Wspólnym elementem posługi diakona oraz pasterskiej władzy biskupa i prezbitera jest troska o lud oraz o duchowe dobro wiernych. Soborowa definicja odnowionej struktury posługi diakona, potwierdzająca że diakoni umocnieni łaską sakramentalną służą Ludowi Bożemu w łączności z biskupem i jego prezbiterium ${ }^{123}$, jest nie tylko wykładnią hierarchicznego współdziałania świętych szafarzy, lecz również podstawą aspektu kanoniczno-prawnego wzajemnej relacji urzędu diakona do pasterskiej władzy biskupa i prezbitera w Kodeksie Prawa Kanonicznego ${ }^{124}$.

\footnotetext{
120 Por. M. Böhnke, Pastoral in Gemainden ohne Pfarrer. Interpretation von c. 517 $\$ 2$ CIC/1983, Essen 1994, s. 34-71; P. Małek, Odnowiona struktura posługi diakona w świetle pasterskiej władzy biskupa i prezbitera według nauki Soboru Watykańskiego II, dz. cyt., s. 241.

${ }^{121}$ KPK, kan. 150: „Temu, kto nie otrzymał jeszcze święceń kapłańskich, nie można ważnie nadać urzędu związanego z pełnym duszpasterstwem, do wypełniania którego potrzebne jest wykonywanie władzy święceń”.

122 Tamże, kan. $521 \$ 1$ : „Aby ktoś mógł ważnie zostać proboszczem, musi posiadać święcenia prezbiteratu”.

${ }^{123}$ Por. KK, n. 29.

124 Por. P. Małek, Odnowiona struktura posługi diakona w świetle pasterskiej władzy biskupa i prezbitera według nauki Soboru Watykańskiego II, dz. cyt., s. 241.
} 
Źródłem kanonu 517 \$ 2 jest soborowa definicja odnowionej struktury posługi diakona, w której szczególna troska o wiernych jest warunkiem wymaganym do możliwości przywrócenia stałej posługi diakona.

Dyrektorium o posłudze i życiu diakonów stałych podkreśla, iż kierowanie rozproszonymi wspólnotami chrześcijańskimi przez diakonów stałych stanowi funkcję misyjną, spełnianą przez nich na terenach, w środowiskach, w warstwach społecznych lub grupach, w których odczuwa się brak prezbitera albo jest on trudno dostępny ${ }^{125}$. Diakon gromadzi wspólnotę wiernych i przewodzi liturgii Słowa Bożego, połączonej z udzielaniem Komunii św., szczególnie w miejscach pozbawionych całkowicie kapłana, a więc gdy niemożliwe jest sprawowanie Eucharystii ${ }^{126}$. Jan Paweł II zauważa, iż „Jest to zastępcza funkcja, którą diakon pełni z upoważnienia Kościoła, kiedy trzeba zaradzić niedostatecznej ilości kapłanów"127. Przy takim sprawowaniu liturgii nie należy zapominać o modlitwie w intencji powołań kapłańskich, ukazując w sposób właściwy ich konieczność we wspólnocie kościelnej. W przypadku obecności diakona, przewodniczenie posłudze pasterskiej nie może być powierzone wiernemu świeckiemu, ani grupie osób. To samo dotyczy również przewodniczenia niedzielnej liturgii $^{128}$.

Według Dyrektorium o posłudze i życiu diakonów stałych, wszystkie kompetencje diakona winny być dokładnie określone na piśmie $\mathrm{w}$ momencie powierzenia mu urzędu ${ }^{129}$.

\footnotetext{
125 Por. DPŻDS, n. 41.

126 Por. KPK, kan. $1248 \$ 2$; Kongregacja ds. Kultu Bożego i Dyscypliny Sakramentów, Direttorio per le celebrazioni domenicali in assenza del presbitero Christi Ecclesia, 2.06.1988, n. 29, EV 11 (1988-1989) 457.

127 Jan Paweł II, Funkcje diakona w postudze duszpasterskiej. Katecheza podczas Audiencji Generalnej, 13.10.1993, n. 4, OR, wyd. pol. 1 (1994), s. 40.

128 Por. DPŻDS, n. 41.

129 Por. tamże.
} 
W przypadku podjęcia przez biskupa decyzji o ustanowieniu Rady Duszpasterskiej, to diakoni uczestniczący w życiu duszpasterskim parafii zostają jej członkami z urzędu ${ }^{130}$.

Liczne możliwości owocnej posługi diakonów oferuje także środowisko diecezjalne. Diakoni posiadający odpowiednie przymioty mogą być członkami instytucji diecezjalnych, zwłaszcza Rady Duszpasterskiej ${ }^{131}$. Mogą też uczestniczyć w synodzie diecezjalnym ${ }^{132}$. Jest to nowa norma prawna, ponieważ - jak słusznie zauważa J. Wroceński - według Kodeksu z 1917 roku zgodnie z zapisem kanonu 358 prawo uczestniczenia w synodzie przysługiwało tylko biskupowi i prezbiterom ${ }^{133}$. Nie mogą jednak być członkami rady kapłańskiej, ponieważ reprezentuje ona wyłącznie kapłanów ${ }^{134}$. W przypadku posiadania odpowiednich kwalifikacji, diakoni mogą być powołani na stanowisko kanclerza ${ }^{135}$, sędziego ${ }^{136}$, asesora ${ }^{137}$, audytora ${ }^{138}$, promotora sprawiedliwości, obrońcy węzła ${ }^{139}$ oraz notariusza $^{140}$. Natomiast diakoni nie mogą pełnić urzędu wikariusza sądowego, pomocniczego wikariusza sądowego ani dziekana, zwanego również wikariuszem rejonowym, albowiem urzędy te są zarezerwowane dla kapłanów ${ }^{141}$.

\footnotetext{
130 Por. Paweł VI, Motu proprio Sacrum diaconatus ordinem, V, 24, AAS 59 (1967) 702; KPK, kan. 536.

${ }^{131}$ Por. Paweł VI, Motu proprio Sacrum diaconatus ordinem, V, 24, AAS 59 (1967) 702 ; KPK, kan. $512 \S 1$.

${ }^{132}$ Por. KPK, kan. $463 \$ 2$; P. Amenta, Partecipazione alla potestà legislativa del Vescovo. Indagine teologico-giuridica su chiesa particolare e sinodo diocesano, Roma 1996, s. 177-196.

${ }^{133}$ Por. J. Wroceński, Rola i zadania prezbiterium w życiu Kościoła partykularnego (Studium prawno-historyczne), Warszawa 1998, s. 64-65.

${ }^{134}$ Por. KK, n. 28; KPK, kan. $495 \$ 1$.

${ }^{135}$ Por. KPK, kan. 482.

${ }^{136}$ Por. tamże, kan. $1421 \S 1$.

137 Por. tamże, kan. 1424.

${ }^{138}$ Por. tamże, kan. $1428 \$ 2$.

139 Por. tamże, kan. 1435.

140 Por. tamże, kan. $483 \$ 1$.

${ }^{141}$ Por. tamże, kan. $1420 \S 4 ; 553 \S 1$.
} 
Innymi sektorami posługi diakonów stałych są instytucje i komisje diecezjalne, duszpasterstwo pewnych środowisk społecznych, zwłaszcza duszpasterstwo rodzin lub grup ludzi, które wymagają specjalnej troski duszpasterskiej, jak na przykład grupy etniczne ${ }^{142}$. W tym kontekście warto wspomnieć, iż wraz z promulgacją Konstytucji Apostolskiej Jana Pawła II Spirituali militum curae powstała możliwość sprawowania posługi diakona w ordynariatach wojskowych. Prawodawca kościelny postanowił, że biskupi diecezjalni oraz kompetentni przełożeni zakonni powinni przydzielić ordynariatowi wojskowemu wystarczającą ilość kapłanów oraz diakonów, nadających się do tego rodzaju pracy ${ }^{143}$. W statutach partykularnych należy ustalić pozycję kościelną ordynariusza wojskowego, kapłanów oraz diakonów, podlegających ordynariatowi wojskowemu w czasie wykonywania przez nich funkcji, a także zasady ich statusu wojskowego ${ }^{144}$.

Ta nowa forma posługi diakonów w ordynariatach polowych odpowiada w szczególny sposób powołaniu oraz misji diakonów stałych. Nie mogą oni pełnić urzędu kapelanów wojskowych, ponieważ prawodawca kościelny określił, że kapelanem jest kapłan, któremu powierza się stałą troskę pasterską o jakąś wspólnotę lub specjalny zespół wiernych ${ }^{145}$. Diakon pełniący posługę w ordynariacie wojskowym może być nazywany duchownym wojskowym clericus militum vel militaris lub diakonem wojskowym diaconus militum vel militaris.

Zgodnie z dyspozycją, zawartą w Motu proprio Sacrum diaconatus ordinem w n. 23, diakon wojskowy wykonuje święte zadania na terenie

\footnotetext{
${ }^{142}$ Por. DPŻDS, n. 42.

143 Jan Paweł II, Constitutio apostolica Spirituali militum, 21.04.1986, AAS 78 (1986) VI, $\$ 2$, s. 483-484: „Episcopi dioecesani necnon competentes Superiores religiosi Ordinariatui castrensi concedant numero sufficienti sacerdotes et diaconos huic muneri idoneos".

${ }^{144}$ Tamże, XIII, $3^{\circ}$, s. 485: „quid de condicione ecclesiastica Ordinarii castrensis ceterorumque sacerdotum vel diaconorum Ordinariatui militari addictorum durante et cessante munere, necnon quae normae servande sint quoad eorum militarem condicionem".

145 Por. KPK, kan. 564.
} 
ordynariatu pod władzą ordynariusza i kapelana wojskowego ${ }^{146}$. Ze względu na specyfikę struktury prawnej ordynariatu, władza, której podlega diakon wojskowy zgodnie z przepisami Konstytucji Apostolskiej Spirituali militum curae, jest władzą złączoną z jurysdykcją biskupa diecezjalnego ${ }^{147}$ oraz miejscowego proboszcza ${ }^{148}$, chyba że z samej natury rzeczy albo ze statutów partykularnych wynika coś innego. Fakt kumulacji władzy spowodowany jest tym, że osoby należące do ordynariatu wojskowego pozostają nadal ściśle związane z Kościołem partykularnym, do którego przynależą z tytułu zamieszkania lub z racji obrządku.

\section{Sankcje karne przewidziane wobec diakonów popełniających przestępstwa}

Kodeks Prawa Kanonicznego stwierdza, iż: „Kościół posiada wrodzone i własne prawo wymierzania sankcji karnych wiernym popełniającym przestępstwo" ${ }^{149}$. Sankcjom tym podlegają wszyscy wierni „ochrzczeni w Kościele katolickim lub do niego przyjęci”, posiadający wystarczające używanie rozumu lub skończony siódmy rok życia, jeśli „ustawa czego innego wyraźnie nie zastrzega” ${ }^{150}$.

Kan. $1312 \$ 1$ do sankcji karnych zalicza kary poprawcze, czyli cenzury, i kary ekspiacyjne. Jeśli chodzi o kary poprawcze, to wyróżnia się wśród nich trzy: ekskomunikę i interdykt, dotyczące wszystkich wiernych, oraz suspensę, stosowaną jedynie wobec duchownych.

\footnotetext{
146 Por. Paweł VI, Motu proprio Sacrum diaconatus ordinem, V, 23, AAS 59 (1967) 702.

147 Jan Paweł II, Constitutio apostolica Spirituali militum, dok. cyt., IV, $3^{\circ}$, s. 483 : „Ordynarii militaris iurisdictio est propria sed cumulativa cum iurisdictione Episcopi dioecesani, nam personae ad Orinariatum pertinentes esse pergunt fideles etami illius Ecclesiae particularis cuius populi portionem ranione domicilii vel ritus efformant".

148 Tamże, VII, s. 484: „Intra ambitum sibi designatum et erga personas sibi commissas, sacerdotes qui in Ordynariatu cappellani nominantur parochorum iuribus gaudent et officiis tenentur, nisi ex rei natura vel statutis particularibus aliud constet, cumulative vero cum loci parocho, ad normam Art. IV".

149 KPK, kan. 1311.

150 Tamże, kan. 11.
} 
Osoba ekskomunikowana nie może posługiwać w sprawowaniu Ofiary eucharystycznej i w innych obrzędach kultu. Ma zakaz sprawowania sakramentów i sakramentaliów, przyjmowania sakramentów, wykonywania urzędów kościelnych lub posług oraz jakichkolwiek innych zadań ${ }^{151}$. Podobne restrykcje, poza zakazem pełnienia kościelnych urzędów, posług lub zadań, dotyczą obłożonych interdyktem ${ }^{152}$. Diakon, ukarany karą suspensy, nie może wykonywać posług, które wynikają z racji otrzymanych święcen ${ }^{153}$. Kary ekspiacyjne, nazywane też zadośćczyniącymi, dotyczą zakazu lub nakazu przebywania na określonym miejscu lub terytorium, pozbawienia władzy i korzystania $z$ urzędu, funkcji, prawa, przywileju, uprawnienia, łaski, tytułu, odznaczenia, karnego przeniesienia na inny urząd oraz wydalenia ze stanu duchownego ${ }^{154}$.

W Kodeksie Prawa Kanonicznego wymienione są ponadto środki karne. Można je nazwać „środkami zaradczymi, ponieważ są stosowane głównie dla zapobieżenia przestępstwom” oraz pokuty, które „,mają na uwadze zastąpienie kary lub jej zwiększenie"155.

\section{Utrata stanu diakońskiego}

Każdy diakon jest powołany do tego, aby ufny w stałą wierność Bogu, żył szlachetnym poświęceniem i nieustannie odnawianą niezmiennością otrzymanego święcenia. Święcenia raz ważnie przyjęte, nigdy nie tracą ważności ${ }^{156}$. Diakon może jednak utracić stan diakoński w następujących przypadkach: „przez wyrok sądowy lub dekret administracyjny, stwierdzający nieważność święceń”157, „przez karę wydalenia nałożoną zgodnie z przepisami prawa” ${ }^{158}$; „przez reskrypt

\footnotetext{
${ }^{151}$ Por. tamże, kan. $1331 \S 1$.

152 Por. tamże, kan. 1332.

153 Por. tamże, kan. $1333 \S 1$.

${ }^{154}$ Por. tamże, kan. $1336 \$ 1$.

155 Tamże, kan. $1312 \S 1$ i 3; por. także, M. Marczewski, Diakonat, dz. cyt., s. 100.

156 Por. KPK, kan. 290.

157 Tamże, kan. 290, $1^{\circ}$.

158 Tamże, kan. 290, 2º por. także, kan. $1394 \$ 1$ i kan. $1395 \S 1-2$.
} 
Stolicy Apostolskiej, którego to reskryptu Stolica Apostolska udziela diakonom tylko z poważnych przyczyn"159.

\section{Streszczenie:}

Podczas obrad Soboru Watykańskiego II zagadnienie stałej oraz odnowionej formy posługi diakona powierzone zostało najwyższemu Prawodawcy oraz Konferencjom Biskupów. Diakonat stały może być przywrócony jako właściwy i trwały stopień hierarchiczny, jeśli kompetentne władze kościelne uznają za słuszne wybranie diakonów, również spośród mężczyzn żonatych, dla zapewnienia wiernym należytej opieki duszpasterskiej. Zadania diakonów stałych sprowadzają się do potrójnej posługi: Słowa, liturgii i miłosierdzia. Diakoni wszystkie powierzone im przez biskupa zadania wykonują w ścisłej łączności z prezbiterami. Jako przynależący do stanu duchownego, diakoni stali związani są obowiązkami i prawami określonym przez Kodeks Prawa Kanonicznego w kanonach 273-289. Święcenia raz przyjęte przez diakonów, nigdy nie tracą ważności, choć w niektórych przypadkach mogą oni utracić stan diakoński.

\section{Summary:}

One of the fruits of the Second Vatican Council was the restoration of the diaconate as a proper and permanent rank in the hierarchy. Paul VI in his Motu proprio, Sacrum diaconatus ordinem estabilished the general norms for the restoration of the permanent diaconate in the Latin Church. According to that document, legitimate assemblies of Bishops or Episcopal Conferences are competent to decide, with the agreement of the Roman Pontiff, if and where, in view of the good of the faithful, the diaconate should be estabilished. As regards the right to establish the permanent diaconate within Institutes of consecrated life and Societies of apostolic life, the document of Paul VI provides that this is reserved to the Holy See, which alone is entitled to examine and approve the opinions of general chapters on the subject. Furthermore, the Holy See has the right to establish the permanent diaconate in other institutes, which profess the evangelical counsels. The status of the deacon carries with it various specific rights and obligations, based upon cann. 273-289 of the Code of Canon Law, which

159 Tamże, kan. 290, $3^{\circ}$. 
address the rights and obligations of clerics, with particular provisions for deacons. Sacred ordination, once validly received, may never be lost. The loss of the clerical state, however, takes place according to the provisions of the canonical norms.

Słowa kluczowe: diakonat stały; diakoni stali; biskup diecezjalny, wyższy przełożony zakonny, Konferencja Biskupów, Kościół partykularny, Instytuty życia konsekrowanego i Stowarzyszenia życia apostolskiego, rozeznanie zdatności, przymioty i wiek kandydata, celibatariusze, żonaci, wdowcy, inkardynacja, obowiązki, prawa i misja kanoniczna diakona stałego, sankcje karne, utrata stanu diakońskiego.

Keywords: permanent diaconate, permanent deacons, diocesan bishop, major superior, Episcopal Conference, particular Church, Institute of consecrated life and Society of apostolic life, discernment of suitability, requirements and age of the candidate, celibate, married, widower, incardination, obligations, rights and canonical mission of the permanent deacon, penal sanctions, loss of the diaconal state.

\section{Biogram}

Ks. Ryszard Selejdak - dr hab. teologii, ur. 17.01.1958 r. w Kromołowie, prezbiter archidiecezji częstochowskiej, patrysta i teolog dogmatyk. Doktorat z teologii patrystycznej - 1991 r. (Papieski Instytut Patrystyczny „Augustinianum” w Rzymie), habilitacja z teologii dogmatycznej - 2011 r. (Uniwersytet Kardynała Stefana Wyszyńskiego w Warszawie). Od 15.05.1991 r. - pracownik watykańskiej Kongregacji Edukacji Katolickiej. Od 1 marca 2002 r. - Dyrektor Departamentu Seminariów tej Kongregacji. Od 22.04.2013 r. - Dyrektor Departamentu Seminariów watykańskiej Kongregacji ds. Duchowieństwa.

\section{Bibliografia:}

Amenta P., Partecipazione alla potestà legislativa del Vescovo. Indagine teologico- giuridica su chiesa particolare e sinodo diocesano, Roma 1996.

Bellia G., Arte o prassi del discernere?, Il diaconato in Italia 154 (2009), s. 5-11. Benedykt XVI, Motu proprio Ministrorum institutio, 16.01.2013, AAS 105 (2013), s. 130-135. 
Böhnke M., Pastoral in Gemainden ohne Pfarrer. Interpretation von c. 517 $\$ 2$ CIC/1983, Essen 1994.

Borras A. -Pottier B., La grazia del diaconato. Questioni attuali a proposito del diaconato latino, Assisi 2005.

Borras A., Les effets canoniques de l'ordination diaconale, RTL 28 (1997), s. $460-475$.

Catechismus ex decreto Concilii Tridentini ad Parochos, Torino 1914.

Denis H. - R. Schaller, Il diaconato nel mondo d'oggi, Milano 1968.

Dyduch J., Diakonat stały w świetle dokumentów Stolicy Apostolskiej, PK 42 (1999) 1-2, s. 56-73.

Gawlik M. -Marczewski M., Dyrektorium o postudze i życiu diakonów statych, RT 46 (1999) 8, s. 197-217.

Jan Paweł II, Adhortacja apostolska Ecclesia in America, 22.01.1999, AAS 91 (1999) 5-88.

Jan Paweł II, Catechesi durante l'Udienza Generale, 6.10.1993, w: Insegnamenti 16 (1993) 2, s. 951-955.

Jan Paweł II, Constitutio apostolica Spirituali militum, 21.04.1986, AAS 78 (1986) 481-486.

Jan Paweł II, Discorso ai diaconi permanenti di Detroit, 19.09.1987, w: Insegnamenti 10 (1987) 3, s. 654-661.

Jan Paweł II, Discorso ai diaconi permanenti in Italia, 16.03.1985, w: Insegnamenti 8 (1985) 1, s. 648-650.

Jan Paweł II, Discorso ai Vescovi dello Zaire in Visita „ad limina”, 30.04.1983, w: Insegnamenti 6 (1983) 1, s. 1110-1117.

Jan Paweł II, Discorso durante l'ordinazione di otto nuovi Vescovi a Kinshasa, $\quad 4.05 .1980, \mathrm{w}$ : Insegnamenti 3 (1980) 1, s. 1109-1115.

Jan Paweł II, Funkcje diakona w postudze duszpasterskiej. Katecheza podczas Audiencji Generalnej, 13.10.1993, OR, wyd. pol. 1 (1994), s. 39-40.

Jan Paweł II, Zarys duchowości diakona. Katecheza podczas Audiencji Generalnej, 20.10.1993, OR, wyd. pol. 1 (1994), s. 41-42.

Klostermann F., Die pastoralen Dienste heute. Priester und Laien im pastoralen Dienst, Linz-Wien-Passau 1980.

Kodeks Prawa Kanonicznego, Poznań 1984.

Konferencja Episkopatu Polski, Wytyczne dotyczace formacji, życia i postugi diakonów stałych w Polsce, 22.01.2004, w: Biblioteka "Niedzieli", t. 157, Częstochowa 2004.

Kongregacja ds. Duchowieństwa, Dyrektorium o posłudze i życiu diakonów stałych, 22.02.1998, Watykan 1998. 
Kongregacja ds. Kultu Bożego i Dyscypliny Sakramentów, Direttorio per le celebrazioni domenicali in assenza del presbitero Christi Ecclesia, 2.06.1998, EV 11 (1988-1989) 442-469.

Kongregacja ds. Kultu Bożego i Dyscypliny Sakramentów, Lettera circolare agli Ordinari Diocesani e ai Superiori Generali degli Istituti di Vita Consacrata e le Società di Vita Apostolica circa la dispensa dagli obblighi sacerdotali o diaconali, Prot. N. 263/97, 6.06.1997, EV 16 (1997) 446-453.

Kongregacja Edukacji Katolickiej, Wytyczne dotyczace formacji diakonów stałych, 22.02.1998, Watykan 1998.

Lodi E., Le esigenze della diaconia secondo la lex orandi, Il diaconato in Italia 88 (1992), s. 19-26.

Małek P., Odnowiona struktura posługi diakona w świetle pasterskiej władzy biskupa i prezbitera według nauki Soboru Watykańskiego II, Kraków 2008.

Marczewski M., Diakonat stały $w$ dokumentach Soboru Watykańskiego II i posoborowego prawodawstwa Kościoła Powszechnego, RT 40 (1993) 6, s. 135-148.

Marczewski M., Diakonat. Sakrament Święceń I, Lublin 2000.

Mesnard G., L'appel du Seigneur. Entretiens sur la vocation, Solesmes 1995.

Messina D., I segni del celebrare e la simbolica diaconale, w: Dal tempio alla strada... la martyria della profezia. Corsi di formazione permanente per Presbiteri e Diaconi, red. M. Russotto, t. IV, Palermo 2002-2003, s. 163-184.

Paweł VI, List apostolski Ecclesiae sanctae, 8.06.1966, AAS 58 (1966) 757-787.

Paweł VI, Motu proprio Ad pascendum, 15.08.1972, AAS 64 (1972) 534-540.

Paweł VI, Motu proprio Sacrum diaconatus ordinem, 18.06.1967, AAS 59 (1967) 697-704.

Petrolino E., Il diaconato permanente alla luce del Magistero post-conciliare, Seminarium 48 (2008) 4, s. 723-750.

Petryk P., Święcenia diakonów, RT 49 (2002) 8, s. 145-164.

Rahner K., Teologie des Diakonats, w: Der Diakon. Ein Werkbuch für den deutschsprachigen Raum, red. A. Fischer - H. Kramer - H. Vorgrimler, Freiburg im Br. 1970, s 26-39.

Righetti M., Storia liturgica, t. I, Milano 1950.

Rincón-Pérez T., El orden de los clérigos o ministros sagrados, Pamplona 2009.

Sekretariat Stanu, List do Kardynała Prefekta Kongregacji ds. Kultu Bożego i Dyscypliny Sakramentów, Prot. N. 122.735, 3.01.1984. 
Selejdak R., Diakonat stały w świetle Biblii i historii Kościoła, Częstochowa 2002.

Selejdak R., Diakonat stały w świetle dokumentów Soboru Watykańskiego II, posoborowego Urzędu Nauczycielskiego Kościoła i narodowych «Rationes institutionis diaconorum permanentium», Warszawa 2010.

Selejdak R., Tożsamość, duchowość, formacja i posługa diakonów stałych, Częstochowa 2003.

Selejdak R., Zarys historyczny diakonatu stałego, Częstochowa 1998.

Schmitz H., Fragen der Inkardinationsrechtes, w: Ecclesia et Ius, red. K von Siepen - J. Weitzel - P. Wirth, Freiburg-Basel-Wien-Frankfurt a. M. 1996, s. 141-167.

Schwendenwein H., Der ständige Diakon, w: Handbuch des katholischen Kirchenrechts, red. Listl J. -Müller H. - H. Schmitz, Regensburg 1983, s. 201-238.

Sobór Watykański II, Lumen gentium, Konstytucja dogmatyczna o Kościele, 21.11.1964, w: Sobór Watykański II, Konstytucje, Dekrety, Deklaracje, Poznań 2002.

Traunecker C., Koptyjska stuła diakońska, Vox Patrum 9 (1989) 17, s. 717-735. Weier J., Der ständige Diakon im Recht der lateinischen Kirche unter besonderer Berücksichtigung der Rechtslage in der Bundesrepublik Deutschland, Essen 1989.

Wprowadzenie do Mszału Rzymskiego, Poznań 1986.

Wroceński J., Rola i zadania prezbiterium w życiu Kościoła partykularnego (Studium prawno-historyczne), Warszawa 1998. 